\title{
Nursery Rearing of Penaeus vannamei in Biofloc Systems with Different Salinities and Organic Carbon Sources
}

\author{
T. Anand, A. Srinivasan, P. Padmavathy, P. Jawahar, J. Stephen Sampathkumar
}

10.18805/IJAR.B-4753

\begin{abstract}
Background: Nursery rearing of Penaeus vannamei became inevitable in the Indian shrimp farming industry, since intensification of culture practices in grow-out systems caused nitrogenous wastes accumulation, diseases, mortality and premature harvests resulted in high food conversion ratio, lower production and profits. The nursery rearing in traditional water exchange systems often getting failure because of nitrogenous waste accumulation. Hence, the present experiment was planned to rear $P$. vannamei in bioflocs systems (BFS) with different salinities and carbon sources.

Methods: The experiment was conducted in $0.22 \mathrm{~m}^{3}$ tanks with three different salinity groups viz., $35 \mathrm{ppt}, 20 \mathrm{ppt}$ and $5 \mathrm{ppt}$ and in each salinity sugar, molasses used as carbon sources to maintain an estimated $\mathrm{C} / \mathrm{N}$ ratio of $15: 1$ and controls without carbon sources. Experimental tanks were stocked @6 post larvae/l, with pre-salinity acclimatized P.vannamei seeds having $0.0029 \pm 0.0003 \mathrm{~g}$ size and nursed for a period of 5 weeks.

Result: The nitrogenous waste accumulation was reduced significantly $(p<0.05)$, also average body weight and survival rate of the seeds showed significant difference $(p<0.001)$ between treatments and controls and within treatments $(p<0.05)$. Salinity, carbon sources and their interaction influenced the growth characteristics significantly $(p<0.01)$. The present experiment manifested promising results of bioflocs nurseries in rearing of $P$. vannamei seeds at different salinities.
\end{abstract}

Key words: Biofloc systems, Heterotrophic biomass, Nitrogenous waste, Nursery rearing, Penaeus vannamei.

\section{INTRODUCTION}

After the introduction of P.vannamei during the year 2010 in India, the shrimp production has increased, over the years the shrimp farmers were also facing many problems in culturing this species viz., unstable water quality due to intensification, size variation, slow growth, running mortality syndrome and disease incidences caused by microsporidian parasite Enterocytozoon Hepatopenaei (EHP), resulted in white feces diseases. Due to this, the size at harvest was reduced over the years and the farmers harvested the crop prematurely (Basavaraja, 2013; Rathipriya et al., 2019). Nursery systems were introduced to overcome the above issues in $P$. vannamei culture practices. But the traditional water exchange systems in nursery rearing often getting failure due to accumulation of nitrogenous wastes, hence, nursery farming of $P$. vannamei showed positive results especially with bioflocs systems (BFS) (Khanjani et al., 2016). The nitrogenous wastes from the nursery systems would be converted into useful heterotrophic bacterial biomass, by continuous addition of carbon sources to alter the $\mathrm{C}: \mathrm{N}$ of the systems in such a way to aid the bioflocs formation under continuous aeration (Avnimelech, 1999; Menaga et al., 2020; Yuvarajan et al., 2021). The use of bioflocs technology would improve the survival, growth and final biomass of cultured animals (Khanjani et al., 2016). There were many studies with different stocking densities using different carbon sources in $P$. vannameibiofloc nursery systems (BNS) but dearth of knowledge in the nursery rearing of $P$. vannamei at different salinities. Hence, the present experiment was carried out for the nursery rearing
Department of Fisheries Science, College of Fisheries Engineering, Dr J. Jayalalithaa Fisheries University, Nagapattinam-611 002, Tamil Nadu, India.

Corresponding Author: T. Anand, Department of Fisheries Science, TNJFU Referral Lab, College of Fisheries Engineering, Tamil Nadu Dr J. Jayalalithaa Fisheries University, Nagapattinam611 002, Tamil Nadu, India. Email: tanand@tnjfu.ac.in

How to cite this article: Anand, T., Srinivasan, A., Padmavathy, P., Jawahar, P. and Sampathkumar, J.S. (2022). Nursery Rearing of Penaeus vannamei in Biofloc Systems with Different Salinities and Organic Carbon Sources. Indian Journal of Animal Research. DOI: 10.18805/IJAR.B-4753.

Submitted: 19-08-2021 Accepted: 20-11-2021 Online: 14-01-2022

of $P$. vannamei in BNS with three different salinities $(35,20$ and $5 \mathrm{ppt}$ ) and two different carbon sources (molasses and sugar) for a period of 5 weeks with an estimated $\mathrm{C}: \mathrm{N}$ of $15: 1$. The growth characteristics of P.vannamei seeds were taken into consideration to assess the system efficiency.

\section{MATERIALS AND METHODS}

The experimental design is given in Table 1. The experiment was conducted as a part of dissertation work during the year 2020 in the Wet Laboratory of College of Fisheries Engineering, Nagapattinam. The experimental tanks were cylindrical in shape with a usable volume of $0.22 \mathrm{~m}^{3}$. The experimental tanks were provided with uninterrupted turbulent aeration from the bottom of tanks through air stones connected with four blowers (each $120 \mathrm{~m}^{3}$ / hour cap.). The seawater with $35 \mathrm{ppt}$ was pumped into reservoir tanks 
through filtration (150-250 $\mu \mathrm{m}$ mesh size) (International Office of Epizootics, 2009) from nearby Vettar estuary and it was diluted with $1 \mathrm{ppt}$ bore water to attain 20 and $5 \mathrm{ppt}$ (Laramore et al., 2001). The tanks were disinfected with calcium hypochlorite ( $35 \%$ concentration of chlorine) to attain a minimum residual chlorine concentration of $10 \mathrm{ppm}$ and which was maintained for 48 hours to kill the disease carriers (International Office of Epizootics, 2009) and after a week residual chlorine level checked and added sodium thiosulphate $(7 \mathrm{mg} / \mathrm{l}$ for each $1 \mathrm{mg} / \mathrm{l}$ of residual chlorine) (Van Wyk and Scarpa, 1999). The water was pumped into experimental tanks and fertilized with dolomite at $10 \mathrm{~g} / \mathrm{m}^{3}$, superphosphate $15 \mathrm{~g} / \mathrm{m}^{3}$ and urea $15 \mathrm{~g} / \mathrm{m}^{3}$ for both treatment and control tanks for 2 to 3 days. Fifty liters of appropriate saline water were autoclaved, to that feed, respective carbon sources were added then aerated for a day and applied uniformly to only the treatment tanks for five days for bioflocs development (Fig 1a) (Panigrahi et al., 2019). To compensate the evaporation loss, once in a week appropriate saline water was added into experimental tanks. A week after stocking the seeds, the control tanks were exchanged $10 \%$ of total volume once a week initially and once in 3 days after 20 days.

The C:N of the feed used was 7:1 and to bring the estimated $\mathrm{C}: \mathrm{N}$ to $15: 1$, for $1 \mathrm{~g}$ of feed added into the tanks $0.347 \mathrm{~g}$ of sugar ( $96.8 \%$ free carbohydrates) and $0.368 \mathrm{~g}$ of molasses ( $91.4 \%$ free carbohydrates) were applied in the treatment tanks every day between 8 to $9 \mathrm{am}$. The total ammoniacal nitrogen (TAN) level in treatment tanks also taken into consideration for the carbon dosage calculation (Avnimelech, 1999; Panigrahi et al., 2019).

At the start of $2^{\text {nd }}$ week, once the total suspended solids (TSS) reached $100 \mathrm{mg} / \mathrm{l}$, (Hostins et al., 2019) experimental tanks were stocked @ 6 post larvae (PL) per litre with specific-pathogen-free, pre-salinity acclimatized (Criales et al., 2011) $P$. vannamei post-larvae (PL) that weighed $0.0029 \pm 0.0003 \mathrm{~g}$. The PL were fed with commercial $P$. vannamei nursery feed with a size range from $0.5 \mathrm{~mm}$ to $1.2 \mathrm{~mm}$. Crude protein, ether extract, crude fiber, total ash, nitrogen-free extract and moisture content of the feed used were $42 \%, 6 \%, 3 \%, 15 \%, 20.5 \%$ and $10.5 \%$ respectively. The animals were fed from 35 to $7 \%$ of average body weight (ABW) (Van Wyk, 1999) and fed six times a day viz., $6 \mathrm{am}$, $10 \mathrm{am}, 2 \mathrm{pm}, 6 \mathrm{pm}, 10 \mathrm{pm}$ and $2 \mathrm{pm}$. The experiments were conducted for 5 weeks from the date, seeds were released.

Water samples were collected between 8 to $9 \mathrm{am}$ at weekly intervals for 8 weeks. Temperature, $\mathrm{pH}$, salinity and dissolved oxygen (DO) were checked every day at 6am and 6pm (HANNA HI 9829 Multiparameter) in the experimental unit. The other water quality parameters like Total alkalinity (TA), TSS, TAN, nitrite nitrogen $\left(\mathrm{NO}_{2}-\mathrm{N}\right)$, nitrate-nitrogen $\left(\mathrm{NO}_{3}-\mathrm{N}\right)$, phosphate phosphorus $\left(\mathrm{PO}_{4}-\mathrm{P}\right)$ and total heterotrophic counts (THC) were measured once in a week using standard methods (American Public Health Association, 2012). The biofloc volume (BFV) was measured using the Imhoff cone (Fig 2).

The ABW, average growth rate, specific growth rate and survival rate of $P$. vannamei seeds were calculated once in a week by using the formula given below. At the end, shrimps were harvested, the survival rate \{Total no of animals harvested divided by the total number of animals stocked multiplied by hundred (\%)\} was calculated (Khanjani et al., 2016) (Fig 1b and c). All statistical analysis was performed using PAST 4.02 software for Windows (Hammer et al., 2001).

Average body weight $(\mathrm{g})=$

Total weight of shrimps collected $(\mathrm{g})$

Number of shrimps

Average growth rate $(\mathrm{g})=$

Final weight of shrimps - Initial weight (g)

Number of days cultured

Specific growth rate $=$

$\underline{\text { Log [Final weight of shrimps - Initial weight }(\mathrm{g})]} \times 100$ Number of days

\section{RESULTS AND DISCUSSION}

\section{Water quality parameters}

The water quality management in the nursery and hatchery systems are bit critical than the grow out ponds since, the larval forms are more susceptible to toxic metabolites. Though there was no significant difference $(p>0.05)$ in the temperature and DO levels of treatments and control they were within the optimum for growing P.vannamei (Emerenciano et al., 2013). DO and salinity is inversely proportional hence, DO levels were slightly higher at $5 \mathrm{ppt}$ treatments (Boyd et al., 2018). The $\mathrm{pH}$, TA and TSS values showed significant difference $(p<0.05)$ between treatments, controls and within treatments. BFV showed significant difference $(p<0.01)$ between and within treatments. The $\mathrm{pH}$, TA and TSS levels were within the optimum range for growing P.vannamei (Van Wyk and Scarpa, 1999; De Morais et al., 2020). Regular addition of carbon sources in the BFS with

Table 1: The experiment design of $P$. vannamei bioflocs nursery rearing systems.

\begin{tabular}{|c|c|c|c|c|c|c|c|c|c|}
\hline \multirow[t]{2}{*}{ Particulars } & \multicolumn{3}{|c|}{35 ppt group } & \multicolumn{3}{|c|}{20 ppt group } & \multicolumn{3}{|c|}{5 ppt group } \\
\hline & & & Control & & & Control & & & Control \\
\hline Carbon source & Sugar & Molasses & $\begin{array}{c}\text { (No carbon } \\
\text { added) }\end{array}$ & Sugar & Molasses & $\begin{array}{c}\text { (No carbon } \\
\text { added) }\end{array}$ & Sugar & Molasses & $\begin{array}{c}\text { (No carbon } \\
\text { added) }\end{array}$ \\
\hline Experimental & T35S & T35M & CL35 & T20S & $\mathrm{T} 20 \mathrm{M}$ & CL20 & T5S & T5M & CL5 \\
\hline
\end{tabular}

tanks marked as 
higher $\mathrm{DO}$ levels resulted in lower $\mathrm{pH}$ due to degradation of organic matter and formation of heterotrophic biomass (Emerenciano et al., 2013). TA was lower than the controls since the assimilation of nitrogenous matter consumed alkalinity in the treatments (Furtado et al., 2014). In the present experiment a reasonable level of TSS content was maintained and PL of P.vannamei might have consumed the bioflocs (Schveitzer et al., 2013; Khanjani et al., 2020).

\section{Nutrient dynamics in bioflocs nursery rearing systems}

The TAN, $\mathrm{NO}_{2}-\mathrm{N}, \mathrm{NO}_{3}-\mathrm{N}$ and $\mathrm{PO}_{4}-\mathrm{P}$ values showed significant difference $(p<0.01)$ between treatments and controls, whereas significant difference was not observed within treatments (Fig 3,4 and 5a to c). It was observed that TAN values started increasing slowly till $5^{\text {th }}$ week, after that it showed downtrend, while $\mathrm{NO}_{2}-\mathrm{N}, \mathrm{NO}_{3}-\mathrm{N}$ started increasing. But in the controls TAN, $\mathrm{NO}_{2}-\mathrm{N}$ and $\mathrm{NO}_{3}-\mathrm{N}$ was gradually increasing from the first week and attained the peak at the $7^{\text {th }}$ week. So, after the bioflocs were established in the treatments, the assimilation was dominated whereas, nitrification was solely responsible for TAN assimilation in the control tanks. This indicated the fact that the heterotrophic bacterial biomass (HBB) in BNS outwitted the nitrifiers in the nitrogenous nutrient assimilation which was an impediment for the development of the nitrifiers in BFS (Cortes-Lorenzo et al., 2015). In BFS insignificant levels of $\mathrm{NO}_{2}-\mathrm{N}$ and $\mathrm{NO}_{3}-\mathrm{N}$ were observed in treatments, which used to happen due to assimilation of nitrogenous compounds. Though there was an increase in the TAN, $\mathrm{NO}_{2}-\mathrm{N}$ and $\mathrm{NO}_{3}-$ $\mathrm{N}$ concentrations in the treatment groups during the first 2 to 3 weeks, it was within optimal level for rearing and growing PL of P.vannamei (Lin and Chen, 2001; Lin and Chen, 2003). The distinction in the levels of TAN, $\mathrm{NO}_{2}-\mathrm{N}$ and $\mathrm{NO}_{3}-\mathrm{N}$ values between treatment and controls served as an evidence that HBB assimilated the TAN in BNS (Avnimelech, 1999). A significant difference in the THC between treatments and controls also expounded the fact very well (Khanjani et al., 2020). The results exhibited that nitrification was the major source of nitrogenous matter oxidation in controls whereas in BNS, assimilation as well as nitrification also served as the major nitrogenous matter oxidation process (Emereniano et al., 2013).

The $\mathrm{PO}_{4}-\mathrm{P}$ values were higher than the controls and similar observations were made in the earlier studies also (Fig $6 a$ to $\mathrm{c}$ ). Unlike the plankton based systems the microbial flocs in the BNS often unable to assimilate the accumulated phosphorus arising out of non-ingested feed, fecal matter and decomposed organic matter hence, periodical removal of excess phosphorus is necessary in such systems (Panigrahi et al., 2019).

\section{Growth characteristics}

Salinity, carbon sources and their interaction showed significant influence $(p<0.05)$ between different treatments in the ABW and survival rate of $P$. vannamei BNS (Table 2). A significant difference $(p<0.01)$ was found in the ABW,

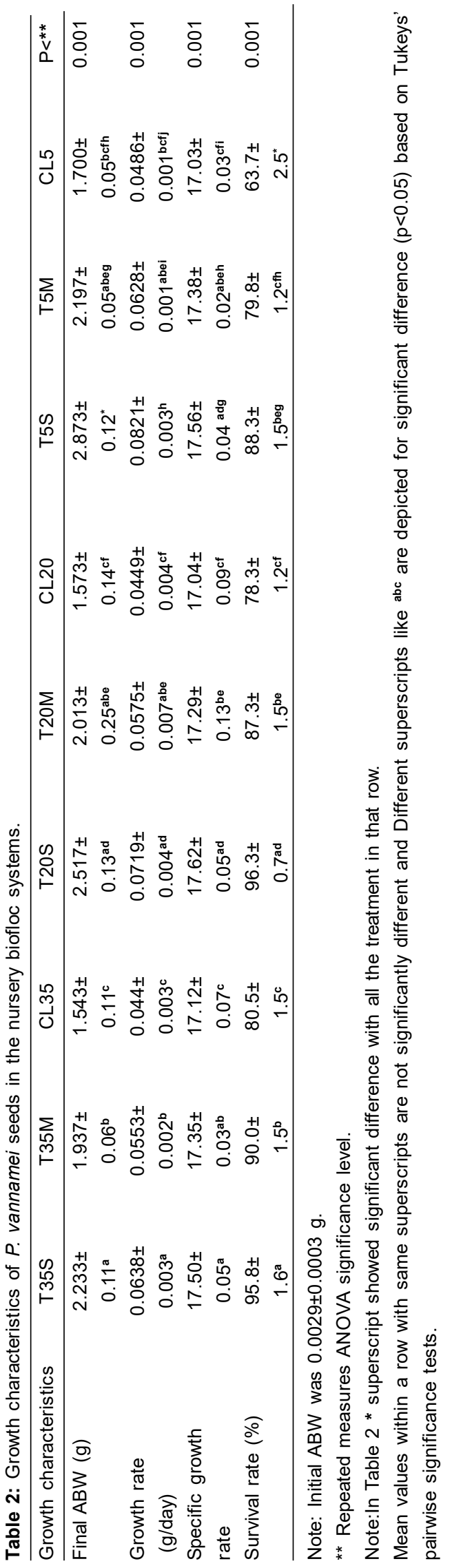



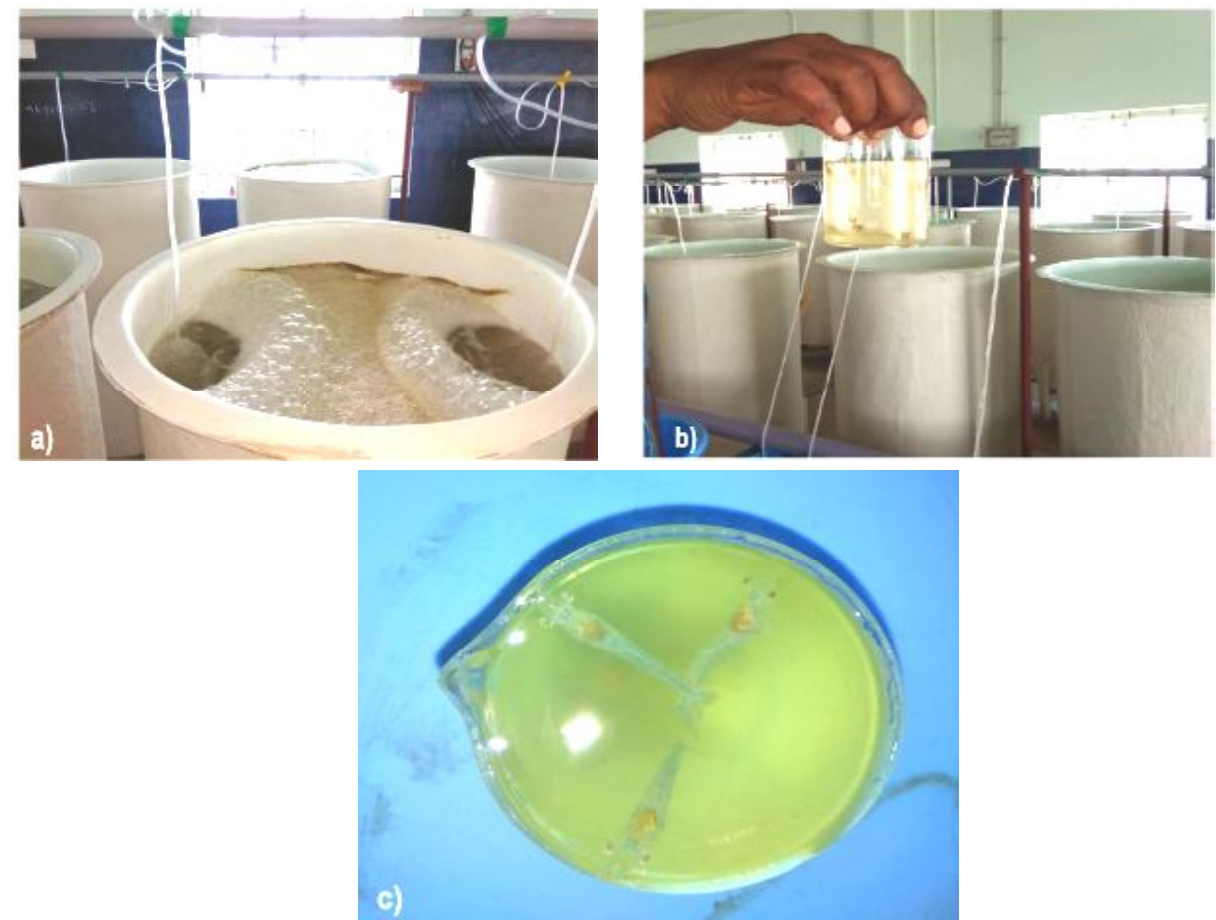

Fig 1: a). Bioflocs developed experimental tank b) and c) Sampling of $P$. vannamei seeds reared in bioflocs systems.
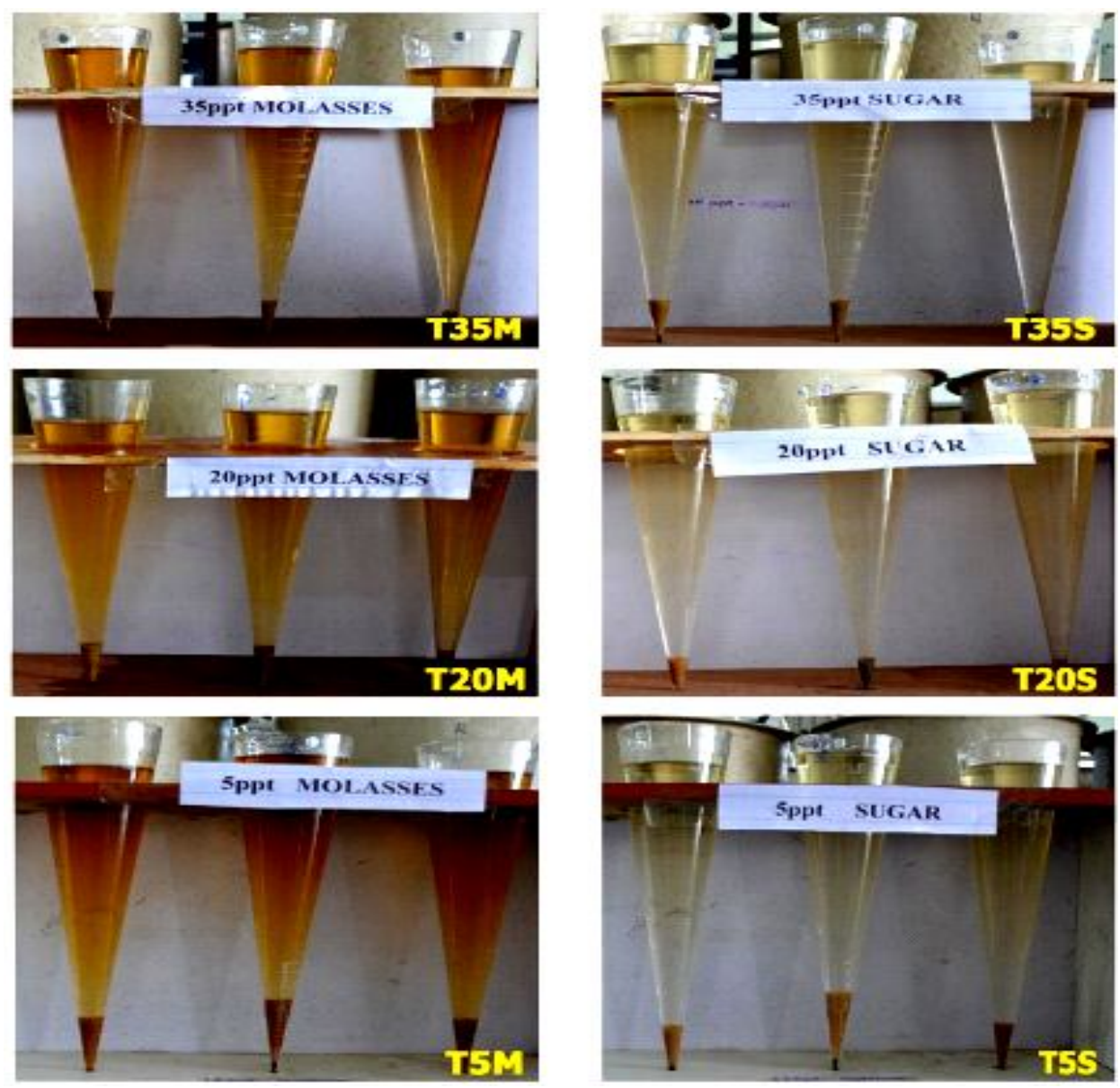

Fig 2: Measuring the biofloc volume (BFV) using Imhoff cone at $4^{\text {th }}$ week of experiment. 
between treatments and controls and within the treatments $(p<0.05)$. Sugar treatments recorded significantly higher growth rate than molasses treatments irrespective of salinity. ABW was 2.23 to $2.87 \mathrm{~g}$ in sugar treated tanks and 1.93 to $2.19 \mathrm{~g}$ in molasses treated tanks and showed an increasing trend with decrease in salinity. Growth rate was higher at
5 ppt than 35 or 20 ppt. Earlier studies reported that use of BFS as nurseries for Penaeid shrimps yielded better growth of cultured organisms with higher $\mathrm{ABW}$ and survival rate if optimal water quality is maintained. In the present experiment irrespective of carbon sources 5 ppt showed higher growth rate than 20 and 35 ppt (Bray et al., 1994).
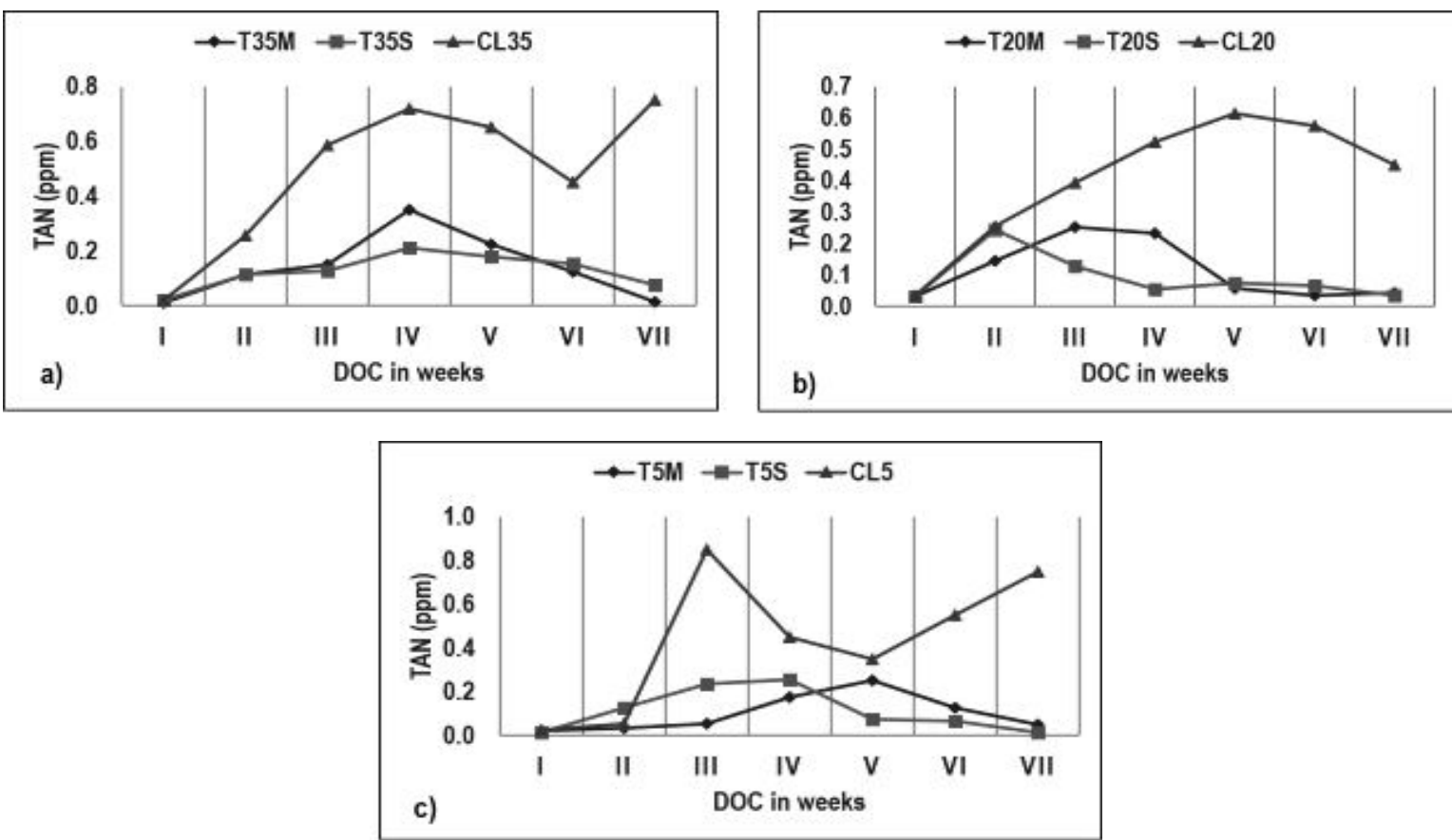

Fig 3: Total ammoniacal level (TAN) in P.vannamei biofloc nursery systems a) at 35 ppt b) at 20 ppt c) at 5 ppt.
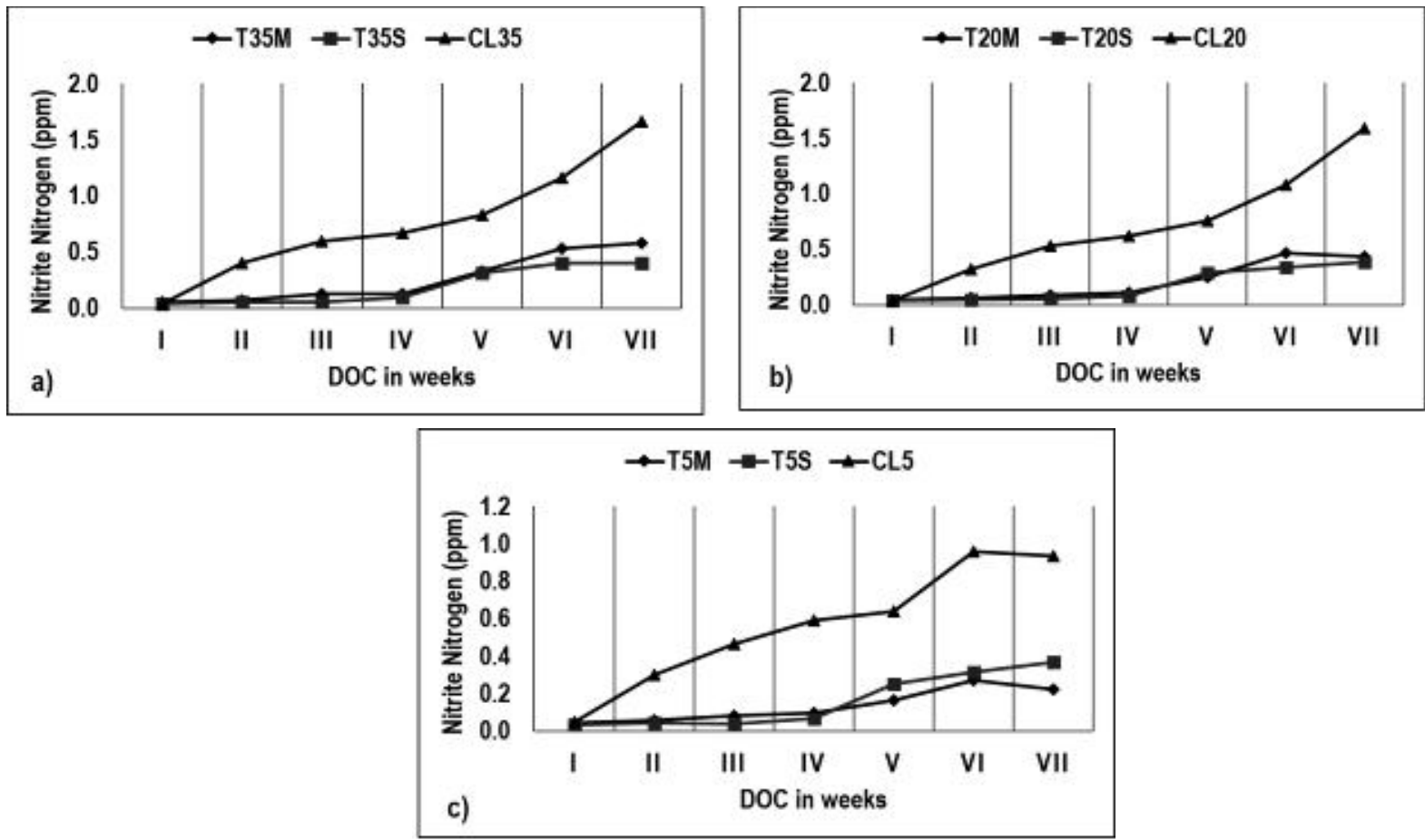

Fig 4: Nitrite nitrogen level $\left(\mathrm{NO}_{2}-\mathrm{N}\right)$ in $P$. vannamei biofloc nursery systems a) at $35 \mathrm{ppt}$ b) at 20 ppt c) at 5 ppt. 

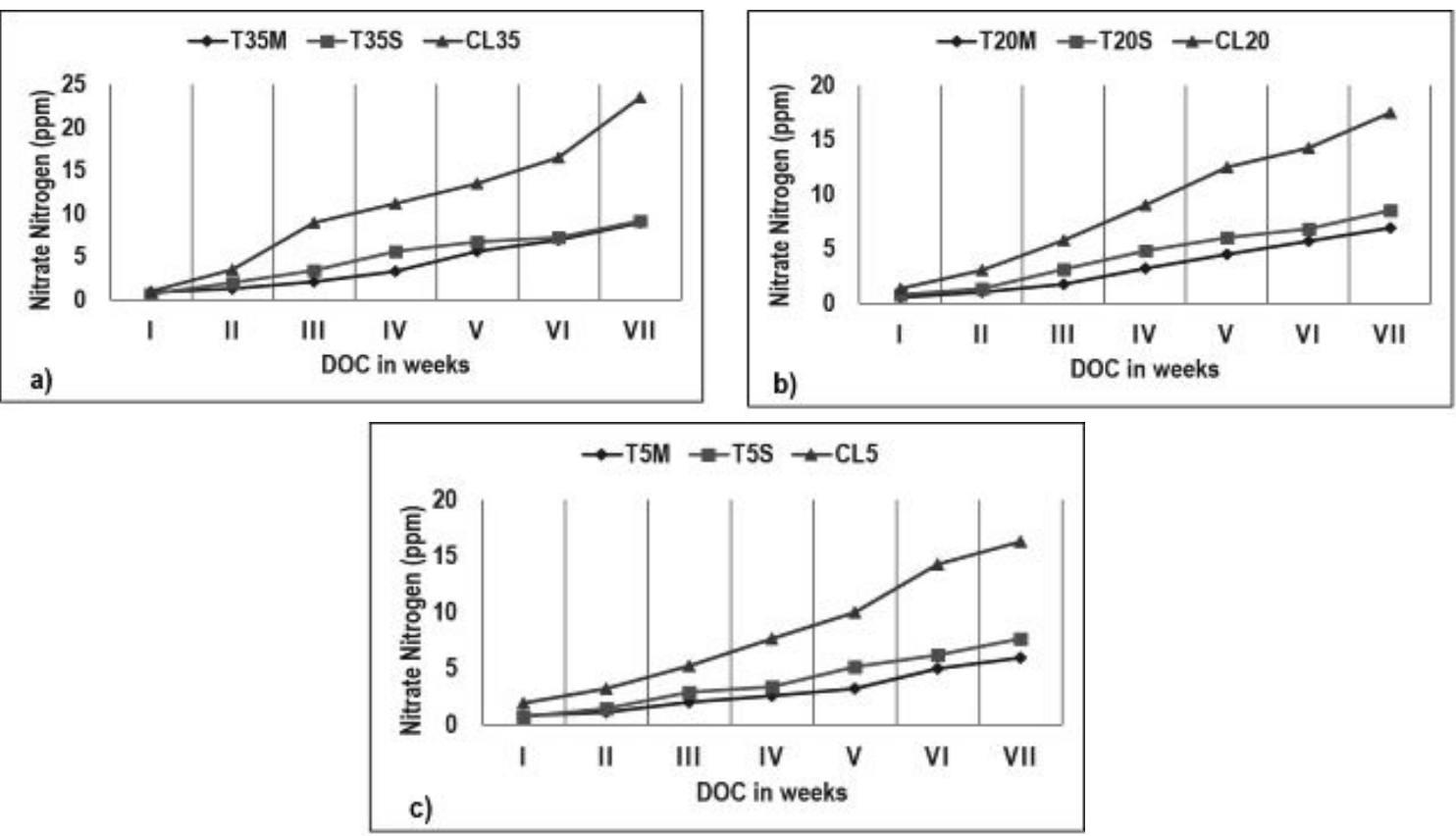

Fig 5: Nitrate nitrogen level $\left(\mathrm{NO}_{3}-\mathrm{N}\right)$ in P.vannamei biofloc nursery systems a) at 35ppt b) at 20ppt c) at 5ppt.
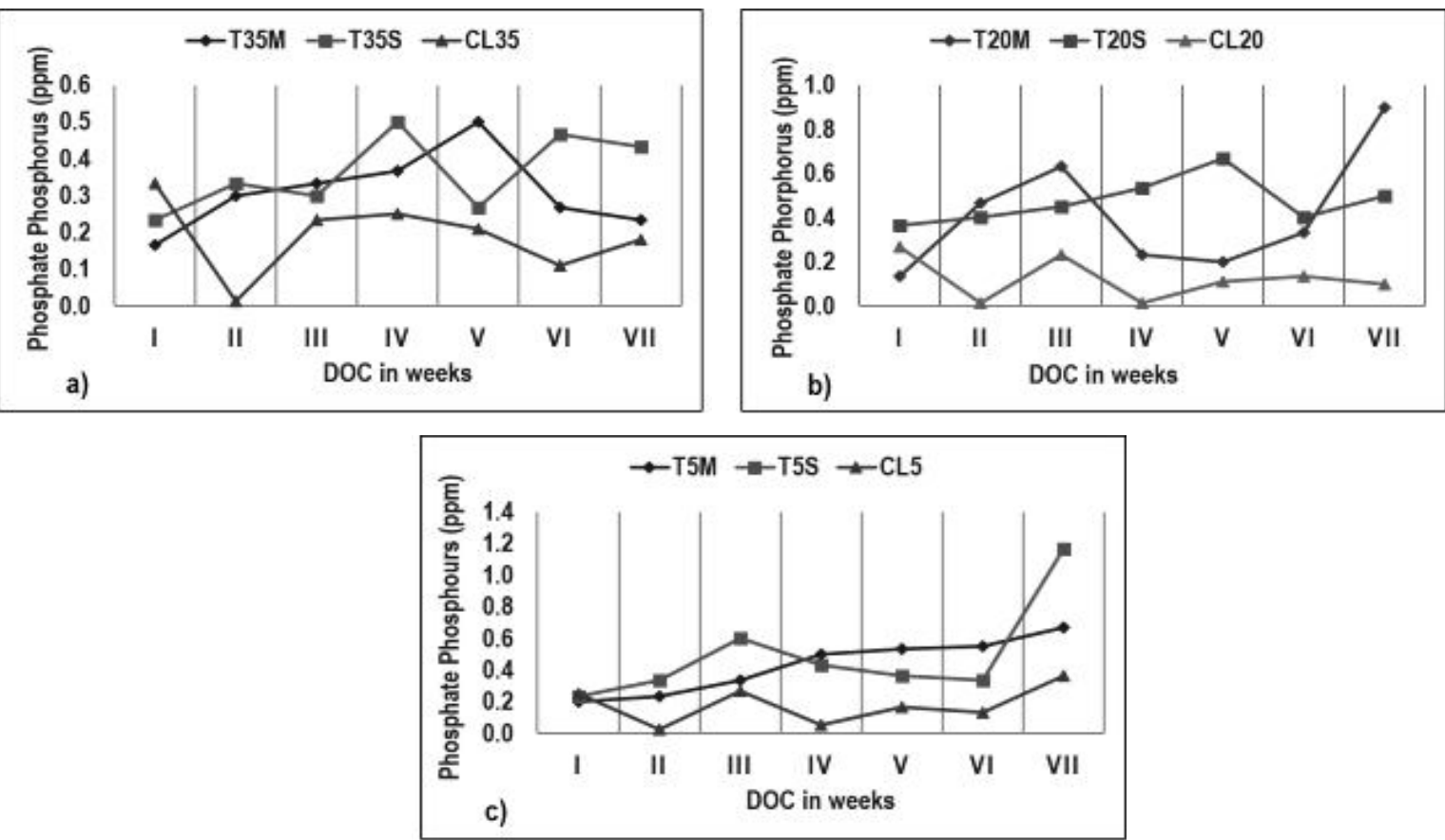

Fig 6: Phosphate phosphorus level $\left(\mathrm{PO}_{4}-\mathrm{P}\right)$ in P.vannamei biofloc nursery systems a) at $35 \mathrm{ppt}$ b) at 20ppt c) at 5ppt

Among various carbon sources applied in the present experiment sugar showed higher ABW irrespective of salinities, this is in accordance with the earlier studies conducted by $\mathrm{Xu}$ et al. (2012).

A significant difference $(p<0.01)$ in the survival rate was observed between the control, treatments and within treatments $(p<0.05)$ except between 35 and 20 ppt. The survival rate was increasing with increase in salinity, similar results were observed with previous studies conducted with low salinities (Li et al., 2007). But P. vannamei can be cultured from 1 to $45 \mathrm{ppt}$ if it is acclimatized for the salinity during the post larval development stage which would modify the ensuing salinity tolerance limits of juveniles (Criales et al., 2011). Among the carbon sources sugar showed higher survival rate ranging from 88.3 to $96.3 \%$ followed by molasses with $79.8 \%$ to $90 \%$ (Table 2 ). 


\section{CONCLUSION}

The nursery rearing of P.vannamei in BFS showed beneficial effects in a wide range of salinity from 5 to $35 \mathrm{ppt}$ than the conventional water exchange systems. The average body weight decreasing and survival rate increasing with increase in salinity. Though the ABW was higher at $5 \mathrm{ppt}$ and survival rate was higher at $35 \mathrm{ppt}$, both $\mathrm{ABW}$ and survival rate was better at 20 ppt salinity and among the carbon sources sugar showed promising results in nursery rearing of $P$. vannamei seeds.

\section{ACKNOWLEDGEMENT}

The author thanks Tamil Nadu Dr. J. Jayalalithaa Fisheries University, Nagapatttinam, Tamil Nadu, India for the funding support for research work in the Ph.D programme.

\section{REFERENCES}

American Public Health Association. (2012). Standard Methods of Examination of Water and Wastewater. (23 $3^{\text {rd }}$ Edn.). APHA, Washington D.C. pp. 1576.

Avnimelech, Y. (1999). C/N ratio as a control element in aquaculture systems. Aquaculture. 176: 227-235.

Basavaraja, N. (2013). Efficacy of macrogard (an immunostimulant) on growth and survival in shrimps and carps. Indian Journal of Animal Research. 57(5): 443-448.

Boyd, C.E., Torrans, E., Tucker, C. (2018). Dissolved Oxygen and Aeration in Ictalurid Catfish Aquaculture. Journal of World Aquaculture Society. 49(1): 1-64.

Bray, W.A., Lawrence, A.L., Leung-Trujillo, J.R. (1994). The effect of salinity on growth and survival of Penaeus vannamei, with observations on the interaction of IHHN virus and salinity. Aquaculture. 122: 133-146.

Cortés-Lorenzo, C., Rodríguez-Díaz, M., Sipkema, D., JuárezJiménez, B., Rodelas, B., Smidt, H., González-López, J. (2015). Effect of salinity on nitrification efficiency and structure of ammonia-oxidizing bacterial communities in a submerged fixed bed bioreactor. Chemical Engineering Journal. 266: 233-240.

Criales, M., Zink, I., Browder, J., Jackson, T. (2011). The effect of acclimation salinity and age on the salinity tolerance of pink shrimp post larvae. Journal of Experimental Marine Biology and Ecology. 409(1-2): 283-289.

De Morais, A.P.M., Abreu, P.C., Wasielesky, W., Krummenauer, D. (2020). Effect of aeration intensity on the biofilm nitrification process during the production of the white shrimp Penaeus vannamei (Boone, 1931) in biofloc and clear water systems. Aquaculture. 514, DOI:10.1016/j.aquaculture.2019.734516.

Emerenciano, M., Cuzon, G., Paredes, A., Gaxiola, G. (2013). Evaluation of biofloc technology in pink shrimp Farfantepenaeus duorarum culture: Growth performance, water quality, microorganisms profile and proximate analysis of biofloc. Aquaculture International. 21(6): 1381-1394.

Furtado, P., Poersch, L., Wasielesky, W. (2014). The effect of different alkalinity levels on Litopenaeus vannamei reared with biofloc technology (BFT). Aquaculture International. 23: $345-358$.
Hammer, O., Harper David, A.T., Ryan, P.D. (2001). Past: Paleontological statistics software package for education and data analysis. Palaeontol Electron. 4(1): 4: 9.

Hostins, B., Wasielesky, W., Decamp, O., Bossier, P., De Schryver, P. (2019). Managing input $C / N$ ratio to reduce the risk of Acute Hepatopancreatic Necrosis Disease (AHPND) outbreaks in biofloc systems - A laboratory study. Aquaculture. 508: 60-65.

Khanjani, M.H., Alizadeh, M., Sharifinia, M. (2020). Rearing of the Pacific white shrimp, Litopenaeus vannamei in a biofloc system: The effects of different food sources and salinity levels. Aquaculture Nutrition. 25: 328-337.

Khanjani, M.H., Sajjadi, M.M., Alizadeh, M., Sourinejad, I. (2016). Nursery performance of Pacific white shrimp (Litopenaeus vannamei) (Boone, 1931) cultivated in a biofloc system: the effect of adding different carbon sources. Aquaculture Research. 48(4): 1491-1501.

Laramore, S., Laramore, C.R., Scarpa, J. (2001). Effect of low salinity on growth and survival of postlarvae and juvenile Litopenaeus vannamei. Journal of The World Aquaculture Society. 32(4): 385-392.

Li, E.C., Chen, L., Zeng, C., Chen, X., Yu, Na., Lai, Q., Qin, J. (2007). Growth, body composition, respiration and ambient ammonia nitrogen tolerance of the juvenile white shrimp, Litopenaeus vannamei, at different salinities. Aquaculture. 265: 385-390.

Lin, Y. and Chen, J. (2001). Acute toxicity of ammonia on Litopenaeus vannamei (Boone) juveniles at different salinity levels. Journal of Experimental Marine Biology and Ecology. 259(1): 109-119.

Lin, Y. and Chen, J. (2003). Acute toxicity of nitrite on Litopenaeus vannamei (Boone, 1931) juveniles at different salinity levels. Aquaculture. 224: 193-201.

International Office of Epizootics. (2009). Manual of diagnostic tests for aquatic animals (4 $4^{\text {th }}$ Edn.). OIE Paris, France. pp.366.

Menaga, M., Felix, S., Charulatha, M., Mohanasundari, C., Gopalakannan, A. (2020). Comparison of fertilization prototype on biofloc development and its characteristics in GIFT Tilapia Culture. Indian Journal of Animal Research. 54(3): 310-316

Panigrahi, A., Sundaram, M., Chakrapani, S., Rajasekar, S., Syama Dayal, J., Chavali, G. (2019). Effect of carbon and nitrogen ratio $(\mathrm{C}: \mathrm{N})$ manipulation on the production performance and immunity of Pacific white shrimp Litopenaeus vannamei (Boone, 1931) in a biofloc-based rearing system. Aquaculture Research. 50: 29- 41.

Rathipriya, A., Anand, T., Uma, A., Karal Marx, K. (2019). Prevelance of disease casused by white spot virus and Enterocytozoon hepatopenaei in Penaeus vannamei shrimp farms in Nagapattinam District, Tamil Nadu, India. International Journal of Current Microbiology and Applied Sciences. 8(6): 2616-2622.

Schveitzer, R., Arantes, R., Costódio, P.F.S., Santo, C.M.do E., Arana, L.V., Seiffert, W.Q. andreatta, E.R. (2013). Effect of different biofloc levels on microbial activity, water quality and performance of Litopenaeus vannamei in a tank system operated with no water exchange. Aquacultural Engineering. 56: 59-70. 
Van Wyk, P. (1999). Nutrition and feeding of Litopenaeus vannamei in intensive culture systems. Farming marine shrimp in Recirculating fresh water systems. [(Ed.) Van Wyk, P., Davis-Hodgkins, M., Laramore, R., Main, K.L., Mountain, J. and Scarpa, J.] Harbor branch Oceanographic Institution, Florida. pp. 125-139.

Van Wyk, P. and Scarpa, J. (1999). Water quality and management. Farming Marine Shrimp in Recirculating Fresh Water Systems. [(Ed.) Van Wyk, P., Davis-Hodgkins, M., Laramore, R., Main, K.L., Mountain, J. and Scarpa, J.] Harbor branch Oceanographic Institution, Florida. pp. 141-161.
Xu, W.J., Pan, L.Q., Zhao, D.H., Huang, J. (2012). Preliminary investigation into the contribution of bioflocs on protein nutrition of Litopenaeus vannamei fed with different dietary protein levels in zero-water exchange culture tanks. Aquaculture. 350: 147-153.

Yuvarajan, P., Antony, C., Gopalakannan, A., Mahadevi, N. (2021). Effect of distillery spent wash as carbon source in biofloc system on nutrient profile of GIFT Tilapia. Indian Journal of Animal Research. DOI: 10.18805/IJAR.B-4321. 